\title{
Comparative Evaluation of SIMPL Silicone Implants and NIT Natural Teat Inserts to Keep the Teat Canal Patent After Surgery
}

\author{
J. Querengässer, ${ }^{*}$ T. Geishauser,† K. Querengässer, ${ }^{*}$ \\ R. Bruckmaier, $\ddagger$ and K. Fehlings $\S$ \\ *Veterinary Clinic Babenhausen, Germany, \\ †Department of Population Medicine, University of Guelph, Canada, \\ ‡Institute of Physiology, Milk and Food Research Center Weihenstephan, \\ Technical University Munich, Germany, \\ §Bavarian Animal Health Service, Grub, Germany
}

\begin{abstract}
The objective of this study was the comparative evaluation of SIMPL silicone implants and NIT natural teat inserts to keep the teat canal patent after teat surgery. The study was performed on 100 teats of 97 cows treated surgically for milk flow disorders. After surgery, 53 teats were administered with SIMPL and 47 with NIT, and rested for several days. Before treatment and 1 and 6 mo later quarter milk flow and milk yield were measured with Lactocorders; quarter milk was examined for somatic cell count (SCC), pathogens, and signs of mastitis (SCC > 100,000 and pathogens detected). Half a year after surgery milk flow, milk yield and SCC were equal from teats that had been inserted with SIMPL or NIT. The odds of detecting pathogens or signs of mastitis in the milk was lower in SIMPL than in NIT teats at this point in time. SIMPL teats stayed in the herd as long as NIT teats. Based on the results, it may be expected that teats inserted with a SIMPL or NIT do not differ long term in regards to milk flow, milk yield, SCC, and risk of removal from the herd. After the use of SIMPL, fewer pathogens may be detected in the milk long term than after the use of NIT.
\end{abstract}

(Key words: teat, insert, udder health)

\section{INTRODUCTION}

Pipe cleaners ("teat dilators") (Naylor, 1927) or teat canulae (Dyekjaer, 1954) have been used historically to keep the teat canal patent after injury. Recent experiments indicate, however, that teat dilators and teat canulae themselves cause injuries and inflammations in the teat; they are often contaminated with microor-

Received October 16, 2001.

Accepted January 19, 2002.

Corresponding author: T. Geishauser; e-mail: tgeishaus@ uoguelph.ca. ganisms and increase the risk of mastitis (Höptner, 1994; Seeh et al., 1997; Querengässer et al., 1999; Bleul et al., 2000; Geishauser and Querengässer, 2001). Teat dilators may also disappear into the teat and act as foreign bodies (Kubicek and Meinecke, 1978; Querengässer et al., 2001a). Thus, teat dilators and teat canulae may not be compatible with the guidelines of animal health care. Recently, silicone implants (SIMPL; profsproducts.com, Germany) and natural teat inserts (NIT; profs-products.com, Germany) have become available to keep the teat canal patent. The composition of the NIT is similar to the natural teat canal sebum. They adjust to the shape of the teat canal and dissolve within several days. Experiments indicate that NIT neither affects SCC and electrical conductivity of the milk nor the appearance of the teat canal lining (Seeh et al., 1997).

The objective of this study was the comparative evaluation of SIMPL silicone implants and NIT natural teat inserts to keep the teat canal patent after teat surgery. We hypothesized that teats inserted with SIMPL or NIT do not differ in regards to milk flow, milk yield, milk quality, and removal from the herd 1 and 6 mo after administration (research hypotheses).

\section{MATERIALS AND METHODS}

\section{Animals}

This study was performed on 97 dairy cows that had been referred to the Veterinary Clinic Babenhausen in Bavaria between May 18, 1999, and February 1, 2000, because of milk flow disorders. The outer skin of the affected teat was mainly intact. A total of 100 hard milking teats were investigated. Only one teat was affected in 94 cows; three cows had two affected teats. Three cows had one blind quarter. The cows originated from 78 herds. One cow each was enrolled from 65 herds, two cows from eight herds, and three or more from five herds. 


\section{Procedures}

On referral, case history was determined, and a clinical examination was performed. Before examination of the teat, cows received xylazine $(0.2 \mathrm{ml}$ of a $2 \%$ solution per $100 \mathrm{~kg}$ of body mass) and oxytocine (20 I.E.) intravenously. All udder examinations were performed at the quarter level. After cleaning the teats, hand milkability was assessed (milkable by hand/not milkable by hand). The teat tip to floor distance $(\mathrm{cm})$, and the teat length $(\mathrm{cm})$ were measured, and the teat tip thickness $(\mathrm{mm})$ was determined with spring-loaded calipers (Hamann et al., 1996; Hauptner, Solingen/Germany). After disinfection, milk samples were taken to determine SCC (1000 cells $/ \mathrm{ml}$ ), and to culture pathogens (type) (DVG, 2000). Mastitis was defined as SCC greater than 100,000 and pathogens detected (DVG, 1994). Teat canal width (mm) was measured with a plug gauge (Johannson, 1957), and teat canal length ( $\mathrm{mm}$ ) with a thelometer (Geishauser and Querengässer, 2000; Thelometer; Eickemeyer, Nashville, TN). Cows were milked with a quarter milking machine equipped with four Lactocorders (Wellnitz et al., 1999) (Foss, Hilleröd, Denmark). The Lactocorders measured peak milk flow $(\mathrm{kg} / \mathrm{min})$, average milk flow and milk yield $(\mathrm{kg})$. Machine milkability was defined as a milk flow greater than $0.1 \mathrm{~kg} / \mathrm{min}$. Upon initial examination, the affected teat was milked for only 1 min to prevent further damage to the teat. The remaining milk was drained with a milking tube and weighed.

To diagnose the cause of the milk flow disorder, we examined all affected teats by using teat endoscopy (Theloscope; Eickemeyer) (Medl et al. 1994; Querengässer 1998, Geishauser and Querengässer, 2001). With the endoscopic findings, teats were classified into three groups as follows: 1 . Rupture in the teat canal area without dislocation of tissue, 2. Rupture in the teat canal area with dislocation of tissue (inversion or eversion), and 3. Others (Querengässer et al., 2001b). An inflammation of the teat cistern lining (cisternitis) was diagnosed when reddening or swelling was visible in the teat cistern during endoscopy. A valve-like stenosis (valve stenosis) was a recurrent milk flow disorder, whereby the milk stream was suddenly interrupted during hand-milking and whereby tissue impairing milk flow like a valve was visible during endoscopy. In partial valve action, milk flow was still measureable ( $\geq 0.1 \mathrm{~kg} / \mathrm{min}$ ), whereas in complete valve action milk flow was not measurable any more $(<0.1 \mathrm{~kg} / \mathrm{min})$ (Table 2).

All milk flow disorders were treated surgically by removing dislocated tissue with a punch, dilating narrowed teat canals with a lancet, or extracting free bodies from the teat cistern with a forceps (Geishauser and

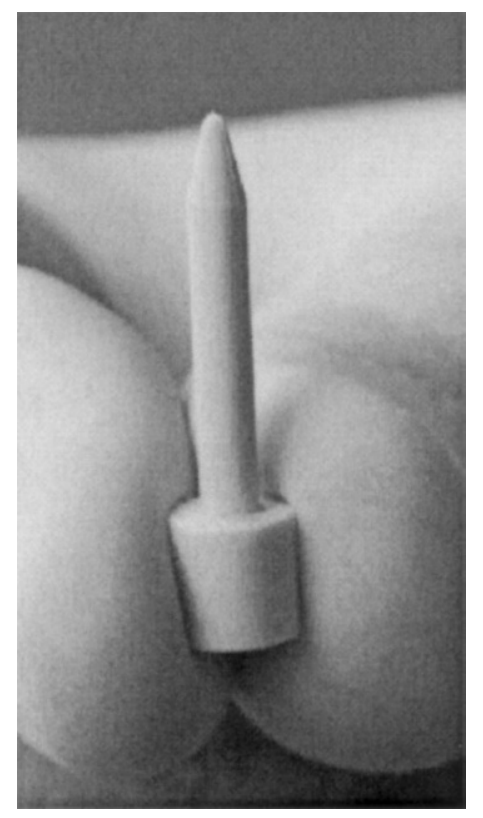

Figure 1. SIMPL (profs-products.com) silicone implant.

Querengässer, 2001). After surgery, an antibiotic (600 mg of cefazolin; Merial, Halbergmoos, Germany) was administered into the teat cistern, either a silicone implant (SIMPL; Figure 1) or a natural teat insert (NIT; Figure 2) was inserted into the teat canal, the teat was bandaged and rested (not milked) for several days. NIT or SIMPL were inserted at random. Depending on teat canal width either a thin $(2.8 \mathrm{~mm})$ or a thick $(3.7 \mathrm{~mm})$

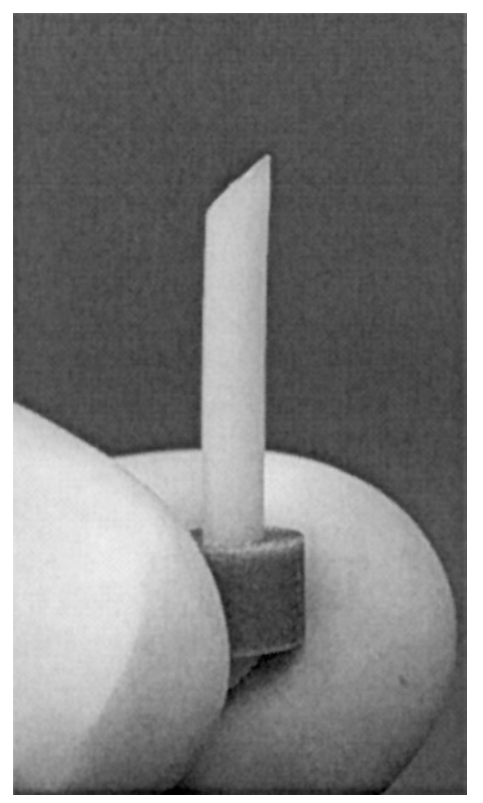

Figure 2. NIT (profs-products.com) natural teat insert. 
Table 1. Case history of 97 cows with milk flow disorders in 100 teats. Milk flow disorders were diagnosed and treated by using endoscopy. After surgery teats were inserted with a silicone implant (SIMPL) or a natural teat insert (NIT) to keep the teat canal patent, and rested for several days. $*=$ SIMPL and NIT groups different at $P<0.1$.

\begin{tabular}{|c|c|c|c|c|}
\hline Parameter & $\begin{array}{l}\text { SIMPL } \\
(\mathrm{n}=53) \\
\%\end{array}$ & Median & $\begin{array}{l}\text { NIT } \\
(\mathrm{n}=47) \\
\%\end{array}$ & Median \\
\hline Brown Swiss (Braunvieh) & 62 & & 70 & \\
\hline Simmental (Fleckvieh) & 19 & & 19 & \\
\hline Holstein (Schwarzbunte) & 15 & & 7 & \\
\hline Other & 4 & & 4 & \\
\hline Tie stall & 64 & & 68 & \\
\hline Free stall & 36 & & 32 & \\
\hline Herd size (lactating cows) & & 35 & & 40 \\
\hline Primiparous & 43 & & 47 & \\
\hline Pluriparous & 57 & & 53 & \\
\hline DIM when presented & & $107^{*}$ & & 88 \\
\hline Duration of illness (days) & & 11 & & 14 \\
\hline Pretreated & 83 & & 57 & \\
\hline \multicolumn{5}{|l|}{ Location of the affected teat } \\
\hline Front left & 11 & & 13 & \\
\hline Front right & 24 & & 8 & \\
\hline Hind left & 42 & & 43 & \\
\hline Hind right & 23 & & 36 & \\
\hline
\end{tabular}

SIMPL or NIT, respectively, was used. Most teats were rested for $2 \times 3 \mathrm{~d}$ (Burkhardt, 1985; Weichselbaum et al., 1995). If the milk showed visible signs of masitits (flakes), then the milk was drained twice daily and an antibiotic administered intracisternally over night. After the resting period, teats were milked regularly. Cows were reexamined 1 and 6 mo later in the herd of origin.

Table 2. Cause and treatment of 100 milk flow disorders. Milk flow disorders were diagnosed and treated by using endoscopy. After surgery teats were inserted with a silicone implant (SIMPL) or a natural teat insert (NIT) to keep the teat canal patent, and rested for several days. ${ }^{*}=$ SIMPL and NIT groups different at $P<0.1$.

\begin{tabular}{lcc}
\hline & $\begin{array}{l}\text { SIMPL } \\
(\mathrm{n}=53) \\
\%\end{array}$ & $\begin{array}{l}\text { NIT } \\
(\mathrm{n}=47) \\
\%\end{array}$ \\
\hline Cause of the milk flow disorder & & \\
Rupture in the teat canal area & & \\
$\quad$ without dislocation of tissue & 39 & 53 \\
$\quad$ with dislocation of tissue & 55 & 45 \\
Others & 6 & 2 \\
Cisternitis & 70 & 57 \\
No valve action & $43^{*}$ & 66 \\
Partial valve action & 15 & 15 \\
Complete valve action & $42^{*}$ & 19 \\
Treatment & & \\
Punch & 93 & 94 \\
Lancet & 53 & 45 \\
Forceps & 9 & 2 \\
Punch and Lancet & 45 & 41 \\
\hline
\end{tabular}

\section{Statistics}

The data were described as medians for continuous variables and as frequencies for categorical variables (descriptive statistics) (Kreienbrock and Schach, 2000). SIMPL teats were compared to NIT teats. One factor, analysis of variance (Kuehl, 1994) was used to test for differences between these two groups in regards to the parameters of the case history. Then, attempts were made to draw conclusions from the data (inductive statistics). Linear regression (Myers, 1990) was used to assess the effect of SIMPL versus NIT on peak milk flow, average milk flow, milk yield, and SCC (dependent variables). Logistic regression (Hosmer and Lemeshow, 1989) was used to assess the effect on the odds of detecting pathogens, the odds of masitis, and the odds of removal from the herd. A separate model was used for each dependent variable and examination. Because SIMPL and NIT teats differed in DIM and the presence of a valve stenosis, the variables DIM (n) and valve stenosis (present vs. not present) were added to the models. The Statistical Analysis System (SAS, 1999) was used for computation. The $P$ value was set at $P$ $<0.1$.

\section{RESULTS}

\section{Descriptive Statistics}

This study was performed predominantly on teats of young brown Swiss cows, kept in tie-stall barns and 
Table 3. Findings from 100 teats with milk flow disorders before examination, 1 and 6 mo later. Milk flow disorders were diagnosed and treated by using endoscopy. After surgery teats were insertd with a silicone implant (SIMPL) or a natural teat insert (NIT) to keep the teat canal patent, and rested for several days. ${ }^{*}=$ SIMPL and NIT groups different at $P<0.1$.

\begin{tabular}{|c|c|c|c|c|c|c|c|c|c|c|c|c|}
\hline \multirow{2}{*}{ Parameter } & \multicolumn{4}{|c|}{$\begin{array}{c}\text { Examination } \\
\text { before treatment }\end{array}$} & \multicolumn{4}{|c|}{$\begin{array}{l}\text { Reexamination } \\
1 \text { mo later }\end{array}$} & \multicolumn{4}{|c|}{$\begin{array}{l}\text { Reexamination } \\
6 \text { mo later }\end{array}$} \\
\hline & \multicolumn{2}{|c|}{$\begin{array}{l}\text { SIMPL } \\
(\mathrm{n}=53)\end{array}$} & \multicolumn{2}{|c|}{$\begin{array}{l}\text { NIT } \\
(\mathrm{n}=47)\end{array}$} & \multicolumn{2}{|c|}{$\begin{array}{l}\text { SIMPL } \\
(\mathrm{n}=53)\end{array}$} & \multicolumn{2}{|c|}{$\begin{array}{l}\text { NIT } \\
(\mathrm{n}=45)\end{array}$} & \multicolumn{2}{|c|}{$\begin{array}{l}\text { SIMPL } \\
(\mathrm{n}=43)\end{array}$} & \multicolumn{2}{|c|}{$\begin{array}{l}\text { NIT } \\
(\mathrm{n}=35)\end{array}$} \\
\hline DIM at examination & & $107^{*}$ & & 88 & & $127^{*}$ & & 107 & & 201 & & 214 \\
\hline Days after initial examination & & & & & & 32 & & 33 & & 186 & & 188 \\
\hline Calving before reexamination & & & & & 6 & & 4 & & 40 & & 31 & \\
\hline Teat tip thickness (mm) & & 14 & & 14 & & 15 & & 14 & & 13 & & 13 \\
\hline Teat canal width (mm) & & 2 & & 2 & & 2 & & 2 & & 2 & & 2 \\
\hline Teat canal length (mm) & & 10 & & 10 & & $10^{*}$ & & 9 & & 10 & & 10 \\
\hline SCC (1000 cells per ml) & & 3977 & & 1794 & & 590 & & 1067 & & 351 & & 478 \\
\hline $\mathrm{SCC}>100,000($ cells per ml $)$ & $98^{*}$ & & 89 & & 81 & & 91 & & 76 & & 82 & \\
\hline Pathogens detected & $74^{*}$ & & 60 & & 66 & & 73 & & $52^{*}$ & & 71 & \\
\hline Milk yield (kg) & & 0.06 & & 0.16 & & 1.55 & & 1.08 & & 1.82 & & 1.51 \\
\hline Drained yield (kg) & & 1.43 & & 1.37 & & 0 & & 0 & & 0 & & 0 \\
\hline Total yield (milked and drained) (kg) & & 1.46 & & 1.50 & & 1.57 & & 1.47 & & 1.81 & & 1.51 \\
\hline Peak milk flow $(\mathrm{kg} / \mathrm{min})$ & & 0.11 & & 0.17 & & 0.45 & & 0.42 & & 0.48 & & 0.50 \\
\hline Average milk flow (kg/min) & & 0.08 & & 0.15 & & 0.31 & & 0.28 & & 0.31 & & 0.36 \\
\hline Milking time $(\min \cdot s)$ & & 1.00 & & 1.00 & & 5.00 & & 4.50 & & 4.50 & & 4.30 \\
\hline Retreated $^{2}$ & 21 & & 25 & & 19 & & 16 & & 2 & & 0 & \\
\hline Present in the herd at examination & 100 & & 100 & & 100 & & 96 & & 81 & & 75 & \\
\hline
\end{tabular}

${ }^{1}$ Mastitis: $>100,000$ cells per $\mathrm{ml}$ and pathogens detected (DVG, 1994).

${ }^{2}$ Retreatment means dilating the teat canal with a lancet at any point in time after initial treatment (Geishauser and Querengässer, 2001).

having been pretreated. Predominantly hind teats were affected by an acute milk flow disorder. In almost all teats, a rupture in the teat canal area was diagnosed that was often associated with cisternitis and valve stenosis. The predominant treatment was the removal of teat canal tissue that impaired milk flow. Teats sub-

Table 4. Pathogens detected in the milk from 100 teats with milk flow disorders before treatment, one and six months later. Milk flow disorders were diagnosed and treated by using endoscopy. After surgery teats were inserted with a silicone implant (SIMPL) or a natural teat insert (NIT) to keep the teat canal patent, and rested for several days.

\begin{tabular}{|c|c|c|c|c|c|c|}
\hline \multirow[b]{2}{*}{ Pathogen } & \multicolumn{2}{|c|}{ Before treatment } & \multicolumn{2}{|c|}{1 mo later } & \multicolumn{2}{|c|}{6 mo later } \\
\hline & $\begin{array}{l}\text { SIMPL } \\
(\mathrm{n}=46) \\
\mathrm{n}(\%)\end{array}$ & $\begin{array}{l}\text { NIT } \\
(\mathrm{n}=41) \\
\mathrm{n}(\%)\end{array}$ & $\begin{array}{l}\text { SIMPL } \\
(\mathrm{n}=44) \\
\mathrm{n}(5)\end{array}$ & $\begin{array}{l}\mathrm{NIT} \\
(\mathrm{n}=43) \\
\mathrm{n}(\%)\end{array}$ & $\begin{array}{l}\text { SIMPL } \\
(\mathrm{n}=27) \\
\mathrm{n}(\%)\end{array}$ & $\begin{array}{l}\mathrm{NIT} \\
(\mathrm{n}=29) \\
\mathrm{n}(\%)\end{array}$ \\
\hline Streptococcus agalactiae & $0(0)$ & $1(2)$ & $0(0)$ & $1(2)$ & $1(4)$ & $4(14)$ \\
\hline Streptococcus esc. positive ${ }^{1}$ & $19(41)$ & $14(34)$ & $11(25)$ & $16(37)$ & $11(41)$ & $10(35)$ \\
\hline Streptococcus esc. negative ${ }^{2}$ & $10(22)$ & $12(27)$ & $11(25)$ & $4(9)$ & $3(11)$ & $3(10)$ \\
\hline Staphylococcus species ${ }^{3}$ & $7(15)$ & $7(17)$ & $5(11)$ & $9(21)$ & $3(11)$ & $5(17)$ \\
\hline Staphylococcus aureus & $4(9)$ & $5(12)$ & $7(16)$ & $4(9)$ & $6(22)$ & $3(10)$ \\
\hline Arcanobacterium pyogenes & $1(2)$ & $2(5)$ & $3(7)$ & $2(5)$ & $1(4)$ & $0(0)$ \\
\hline Coliforms & $5(11)$ & $1(2)$ & $5(11)$ & $4(9)$ & $1(4)$ & $1(3)$ \\
\hline Others $^{4}$ & $0(0)$ & $0(0)$ & $2(5)$ & $3(7)$ & $1(4)$ & $3(10)$ \\
\hline
\end{tabular}

${ }^{1}$ Strept. esc. positive: Strept. uberis, Enterococci (DVG, 2000).

${ }^{2}$ Strept. esc. negative: Strept. dysgalactiae, Strept. Lancefield group C, G and L (DVG, 2000).

${ }^{3}$ Staph. species: except Staph. aureus.

${ }^{4}$ Others: Enterobacteriaceae, Proteus, Serratia marcescens, pseudomonads, yeasts. 
Table 5. Effects of SIMPL versus NIT on peak milk flow $(\mathrm{kg} / \mathrm{min})$, average milk flow $(\mathrm{kg} / \mathrm{min})$, milked yield $(\mathrm{kg})$ or SCC (million cells per $\mathrm{ml}) 1$ or 6 mo after treatment. Estimates, standard errors (SE) and $P$ values are given.

\begin{tabular}{|c|c|c|c|c|c|c|c|c|c|}
\hline \multirow[b]{2}{*}{ Variable } & \multicolumn{3}{|c|}{ Before treatment } & \multicolumn{3}{|c|}{1 mo later } & \multicolumn{3}{|c|}{6 mo later } \\
\hline & Estimate & $\mathrm{SE}$ & $P$ & Estimate & $\mathrm{SE}$ & $P$ & Estimate & SE & $P$ \\
\hline Peak milk flow & 0.015 & 0.028 & 0.59 & 0.075 & 0.042 & 0.08 & 0.022 & 0.051 & 0.67 \\
\hline Average milk flow & 0.014 & 0.021 & 0.53 & 0.075 & 0.032 & 0.02 & -0.004 & 0.040 & 0.92 \\
\hline Milked yield & 0.080 & 0.042 & 0.06 & 0.406 & 0.150 & 0.01 & 0.112 & 0.252 & 0.66 \\
\hline SCC & 1.046 & 1.106 & 0.35 & -1.051 & 0.875 & 0.23 & -0.773 & 0.730 & 0.29 \\
\hline
\end{tabular}

sequently inserted with SIMPL were more DIM and showed valve stenosis more frequently when presented than teats that were inserted with NIT. In the milk from SIMPL teats cells, pathogens, and mastitis were diagnosed more frequently on referral than in the milk from NIT teats. SIMPL and NIT milks did not differ in regards to pathogens; Streptococci were the pathogens detected most frequently (Tables 1 to 4 ).

\section{Inductive Statistics}

Accounting for the differences between SIMPL and NIT teats in DIM when presented and presence of valve stenosis, the odds of detecting pathogens or the odds of mastitis signs tended to be higher before treatment in the milk from teats subsequently adminstered with a SIMPL than in the milk from teats subsequently inserted with a NIT. One month after treatment, milk flow and milk yield from SIMPL teats were significantly higher than that from NIT teats. At that point in time, no significant differences between SIMPL and NIT teats were found regarding SCC, the odds of detecting pathogens, the odds of mastitis, or the odds of removal from the herd. Half a year after treatment, the odds of detecting pathogens in the milk and the odds of mastitis were lower in SIMPL teats than in NIT teats. At that point in time, SIMPL and NIT teats did not differ in regards to peak milk flow, average milk flow, milk yield, SCC, or removal from the herd (Tables 5 and 6).

\section{DISCUSSION}

The findings of this study indicate that teats inserted with SIMPL after surgery are more milkable short term than teats inserted with a NIT. SIMPL made from silicone with a constant diameter may keep the teat canal patent better than NIT made of wax disintegrating after use. However, long term, SIMPL and NIT seem to be equally helpful to restore milkablility. Higher milk yield from SIMPL teats short term may be explained by better milkability short term (Göft et al., 1994). Long term, equal milk yields may be exspected after the use of SIMPL or NIT. The findings further indicate that milk quality is better after the use of SIMPL than after the use of NIT long term. SIMPL teats are at lower risk of detecting pathogens or signs of mastitis in the milk than are NIT teats. No differences, however, may be expected in SCC. While the risk of detecting pathogens decreased throughout the study period after the use of SIMPL $(P=0.03)$, it did not change after the use of NIT $(P=0.48)$. This finding seems hard to explain because SIMPL and NIT are made of similarly tissue-friendly materials and are both sterile (Geishauser and Querengässer, 2001). Earlier studies have shown that the insertion of a NIT into healthy teat canals for several days does not affect udder health (Seeh et al. 1997). The differences may be attributed to differences in the packaging of the products used in this study. SIMPL were packaged in blisters, whereas NIT were packaged in vials. It may be hypothesized that the removal of SIMPL from blisters was associated with lesser risk of contamination than the removal of NIT from vials. When removing the SIMPL from the blister only the outer end of the SIMPL is touched. However, when removing the NIT from the vial, the inner end of the NIT often got in contact with the palm. The contamination of the inner end of the NIT may increase the risk of in-

Table 6. Effects of SIMPL versus NIT on the odds of detectin pathogens, signs of mastitis or removal from the herd 1 or 6 mo after treatment. Odds ratios (OR), 90\% confidence limits $(90 \% \mathrm{Cl})$, and $P$-values are given.

\begin{tabular}{|c|c|c|c|c|c|c|c|c|c|c|c|c|}
\hline \multirow[b]{2}{*}{ Variable } & \multicolumn{4}{|c|}{ Before treatment } & \multicolumn{4}{|c|}{1 mo later } & \multicolumn{4}{|c|}{6 mo later } \\
\hline & OR & $90 \%$ & CL & $P$ & OR & $90 \%$ & CL & $P$ & OR & $90 \%$ & CL & $P$ \\
\hline Pathogens detected & 2.09 & 0.98 & 4.44 & 0.11 & & & & 0.28 & 0.35 & 0.15 & 0.83 & 0.05 \\
\hline Mastitis & 2.09 & 0.98 & 4.44 & 0.11 & & & & 0.27 & 0.44 & 0.20 & 1.00 & 0.10 \\
\hline Removal from the herd & & & & & & & & 0.55 & & & & 0.40 \\
\hline
\end{tabular}


fecting the quarter. This hypothsis, however, needs further study. Nevertheless, it has led the manufacturer to now package the NIT in blisters. Factors associated with herd or cow are less likely to explain the differences in the quarter infection risk because the variables herd or cow did not significantly contribute to the models used. SIMPL teats stayed in the herd as long as NIT teats, which may indicate that milkability after treatment was more important to the herdsman than milk quality.

It may be concluded from this study that SIMPL and NIT are equally useful to keep the teat canal patent after surgery long term. SIMPL may yield better milk quality than the NIT used.

\section{REFERENCES}

Bleul, U., C. Seeh, J. P. Teifke, R. Hospes, and H. Bostedt. 2000. Resultate endoskopischer, sonographischer und histologischer Untersuchungen an der Zitzenzisternenschleimhaut des Rindes nach Behandlung mit Wollzitzenstiften. Prakt. Tierarzt. 81:590-601.

Burkhardt, H. 1985. Auswirkungen des partiellen Trockenstellens eines Euterviertels beim Rind auf Milchmenge und Milchqualität. Diss., Vet.-Med. Fak., Zürich.

Deutsche Vetreinärmedizinische Gesellschaft e.V. 1994. Leitlinien zur Bekämpfung der Mastitis des Rindes als Herdenproblem. DVG, Fachgruppe "Milchhygiene", Sachverständigenausschuss "Subklinische Mastitis", Kiel, 3. Auflage, ISBN 3-930511-03-7.

Deutsche Vetreinärmedizinische Gesellschaft e.V. 2000. Leitlinien zur Entnahme von Milchproben unter antiseptischen Bedingungen und Leitlinien zur Isolierung und Identifizierung von Mastitiserregern. DVG, Fachgruppe "Milchhygiene", Sachverständigenausschuss "Subklinische Mastitis", ISBN 3-930511-81-9.

Dyekjaer, E. 1954. Nebactin-Pattekanyler. Medlemsbl. Dan. Dyrlaegefor. 6:92-94.

Geishauser, T., and K. Querengässer. 2000. An evaluation of teat canal length in teats with milk flow disturbances. J. Dairy Sci. 83:1976-1980.

Geishauser, T., and K. Querengässer. 2001. Untersuchungen zur Sterilität von Zitzenstiften. Prakt. Tierarzt. 82:367-370.

Geishauser, T., and K. Querengässer. 2001. Using teat endoscopy (theloscopy) to diagnose and treat milk flow disorders in cows. Bov. Pract. 35:156-164.

Göft, H., J. Duda, A. Dethlefsen, and H. Worstorff. 1994. Untersuchungen zur züchterischen Verwendung der Melkbarkeit unter
Berucksichtigung von Milchflußkurven. Züchtungskunde 66:23-37.

Hamann, J., G. A. Mein, and B. Nipp. 1996. Recommended method for measuring changes in thickness of the bovine teat with springloaded calipers. J. Dairy Res. 63:309-313.

Höptner, C. 1994. Documentazione sugli effetti collaterali nell'applicazione di stiloidi e caterteri mammari nella bovina. Universitá Milano, Facoltá di Medicina Veterinaria, Tesi di Laurea.

Hosmer, D. W., and S. W. Lemeshow. 1989. Applied Logistic Regression. Wiley, New York.

Johansson, I. 1957. Untersuchungen über die Variation in der Euterund Strichform der Kühe. Z. Tierz. Züchtungsbiol. 70:233-270.

Kreienbrock, L., and S. Schach. 2000. Epidemiologische Methoden, 3. Auflage, Verlag Spektrum, Heidelberg and Berlin.

Kubicek, J., and B. Meinecke. 1978. Fremdkörper in der Zitze des Rindes. Tierärztl. Umsch. 33:140-143.

Kuehl, R. 1994. Statistical principles of research design and analysis. Duxbury Press. Belmont, CA.

Medl, M., K. Querengässer, C. Wagner, S. Paarmann, and P. Rüsch. 1994. Zur Abklärung und Behandlung von Zitzenstenosen mittels Endoskopie. Tierärztl. Prax. 22:532-537.

Myers, R. H. 1990. Classical and Modern Regression with Applications. 2nd ed. Duxbury Press, Belmont, CA.

Naylor, H. W. 1927. Dilator. United States Patent 1,625,906.

Querengässer, K. 1998. Die Endoskopie der Rinderzitze. Diss., Vet.Med. Fak., Zürich.

Querengässer, K., T. Geishauser, C. Höptner, M. Medl, and F. Tradati. 1999. Effects of teat dilators and teat cannulas on udder health. Bovine Pract. 33:130-135.

Querengässer, K., T. Geishauser, J. Querengässer, R. Bruckmaier, K. Fehlings, and H. Graf. 2001a. Zitzenstifte als freie Fremdkörper in der Zitze des Rindes-zwei Fallberichte. Prakt. Tierarzt. 82:43-49.

Querengässer, K., T. Geishauser, J. Querengässer, M. Nitschke, T. Melle, R. Bruckmaier, and K. Fehlings. 2001b. Milchabflußstörung beim Rind-Befunde von 244 Fällen. Prakt. Tierarzt 82:816-826.

SAS. 1999. SAS/STAT Software. Version 8.0, SAS Institute, Cary, NC. Seeh, C., R. Schlenstedt, K. H. Stengel, T. Geishauser, K. Failing, M. Zschöck, and H. Bostedt. 1997. Prüfung eines neuartigen Strichkanalstabes zur Behandlung von Strichkanalwunden unter besonderer Berücksichtigung der endoskopisch dokumentierten Schleimhautverträglichkeit im Vergleich zu konventionellen Zitzenstiften und Verweilkanülen. Dtsch. Tierärztl. Wschr. 104:277-284.

Weichselbaum, H., W. Baumgartner, and G. Schoder. 1995. Einfluß der Dauer des temporären Trockenstellens eines Euterviertels bei Kühen auf Milchmenge und Milchqualität. Dtsch. Tierärztl. Wschr. 102:353-358.

Wellnitz, O., R. M. Bruckmaier, and J. W. Blum. 1999. Milk ejection and milk removal of single quarters in high yielding dairy cows. Milchwissenschaft 54:303-306. 